\title{
Comparative Intestinal Histomorphology of Five Species of Phyllostomid Bats (Phyllostomidae, Microchiroptera): Ecomorphological Relations with Alimentary Habits
}

\author{
Histomorfometría Comparativa de Intestino de Cinco Especies de Murciélagos Phyllostomideos \\ (Phyllostomidae, Microchiroptera): Relaciones Ecomorfológicas con Hábitos Alimentarios

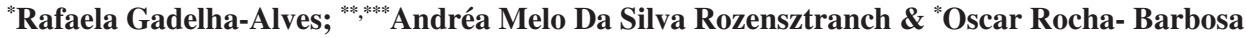

GADELHA-ALVES, R.; ROZENSZTRANCH,A. M. S. \& ROCHA-BARBOSA, O. Comparative intestinal histomorphology of five species of Phyllostomid Bats (Phyllostomidae, Microchiroptera): ecomorphological relations with alimentary habits. Int. J. Morphol., 26(3):591-602, 2008.

SUMMARY: The intestines of Sturnira lilium, Phyllostomus hastatus, Carollia perspicillata, Glossophaga soricina and Desmodus rotundus were analized through macroscopic, morphometric and light microscopy studies. The species studied presented some common characteristics generally found in bats, such as the absence of a caecum and an appendix. The frugivorous bat $\mathrm{S}$. lilium has a longer intestine than the other species. The intestinal epithelium is of the simple columnar type, constituted of absorptive cells characterized by microvilli and goblet cells, which in all the species proved to be PAS + and AB +. These cells presented some differences in quantity and in distribution among the species. The intestinal mucosa presented morphologic and morphometric differences, such as the shape and size of villi as well as the length of the crypts of Lieberkühn. Histologically the different intestinal portions could be distinguished: in the middle portion we found few goblet cells and long villi; in the distal portion we found an increase in goblet cells and a decrease in villi height; and in the large intestine no villi were found, but rather abundant intestinal glands with numerous goblet cells. In C. perspicillata, P. hastatus and G. soricina we could observe Peyer`s patches in the distal portion near the large intestine, whereas in D. rotundus and S. lilium we found aggregations of lymphoid nodulous tissue distributed along the tube. In all species we observed the presence of Paneth cells at the base of the crypts of Lieberkühn. We could observe differences among the species in the distribution of collagen in the small intestine submucosa and serosa. The outer muscular layer has one circular layer and a longitudinal layer, the circular layer increasing in thickness along the tube. Large intestine characteristics are uniform among the species. Structures such as the taenia coli and the appendices epiploicae were absent. These results should contribute not only to improve understanding of bat morphology, but also to provide grounds for the evaluation of evolutionary models on the adaptive radiation of phyllostomid feeding habits.

KEY WORDS: Intestines; Bats; Phyllostomidae; Histology; Histochemistry; Micrometry; Ecomorphology.

\section{INTRODUCTION}

The family Phyllostomidae, endemic to the Americas, constitutes the most diverse and most widely distributed family of Neotropical bats. It is represented by the New World leaf-nosed bats, and is considered the third biggest family of Chiroptera, with 50 genera and 145 species grouped in several subfamilies and tribes (Koopman, 1993; Giménez, 1998). The evolutionary history of these bats is marked by a great adaptive radiation associated with feeding habits, including insectivorous, frugivorous, nectarivorous, carnivorous, omnivorous and sanguivorous diets (Gardner, 1977).

The first detailed study of the chiropteran gastrointestinal tract morphology dates from the end of the 19th century. Robin (1881) presented information which was new for the time, in addition to an excellent review of the literature published until then. In the $20^{\text {th }}$ century, advances

Laboratório de Zoologia de Vertebrados (Tetrapoda - LAZOVERTE) - Departamento de Zoologia, IBRAG - Universidade do Estado do Rio de Janeiro (UERJ), Brazil. Rua São Francisco Xavier, 524 - Maracanã 20550-013, Rio de Janeiro, RJ, Brazil. E-mail: obarbosa@uerj.br.

** Laboratório de Sistemática e Evolução de Mamíferos - Departamento de Vertebrados, Setor de Mastozoologia, Museu Nacional/Universidade Federal do Rio de Janeiro (MN/UFRJ), Brazil.

**** Laboratório de Histoquímica, Instituto de Biologia, Universidade do Estado do Rio de Janeiro (UERJ), Brazil.

Part of a M.Sc. dissertation (Rafaela Gadelha-Alves). 
in histological techniques and the betterment of microscopes led to a boom in microscopic studies.

The macro- and microscopic (histological) anatomies of the gastrointestinal tract or its parts have been well reported for numerous species of Microchiroptera, e.g. Schultz (1965); Rouck \& Glass (1970); Forman (1971, 1972, 1973), Kamiya \& Pirlot (1975); Madkour (1977); Okon (1977); Forman et al. (1979); Ishikawa et al. (1985). However, these works represent a scarce body of information, in view of the as yet unstudied diversity of Neotropical chiropterans.

Although there is a body of literature dealing with morphological descriptions of the chiropteran gastrointestinal tracts, it is not only insufficient, but in addition almost totally lacking in a comparative analysis consistent with the existing diversity of food habits.

Comparative analysis of chiropteran gastrointestinal tract morphology can undoubtedly evidence important features to further our knowledge on the phylogenetic relations of this group, as well as to better understand the evolutionary process as a whole, by means of comparative data on the relation between adaptative radiation and availability of resources in the environment (Forman et al.). These comparative studies can additionally subsidize hypotheses for the understanding of the relations between feeding habits and the digestive physiology of Neotropical bats (Bhide, 1979).

In the present work we carried out a comparative study on the intestine histomorphology of five representatives of family Phyllostomidae, so as to acquire more knowledge on the structural components which make up these tissues. Such results will contribute to a better understanding of these bats' ecomorphology and thus provide grounds to assess evolutionary models on the adaptative radiation of phyllostomid feeding habits.

\section{MATERIAL AND METHOD}

We studied 54 bats representing the 5 Phyllostomidae subfamilies: Sturnira lilium, frugivorous (Stenodermatinae); Phyllostomus hastatus, omnivorous (Phyllostominae); Carollia perspicillata, frugivorous, but also insectivorous (Carolliinae); Glossophaga soricina, nectar-polinivorous, but also consuming insects and fruits (Glossophaginae); and Desmodus rotundus, sanguivorous (Desmodontinae). These animals were captured in a joint effort with the team of researchers from the Laboratory of Mammalian Systematics and Evolution from the National Museum/UFRJ, through collections carried out in Carmo Municipality, Rio de Janeiro
State (July 1999/ October and November 1999), and in Serra da Bodoquena and Bonito regions in Mato Grosso do Sul State (July 2000 / January and February 2001).

Samples of the gastrointestinal tract for microscopic study were obtained following a protocol consisting of anesthesia, sorting, weighing, measuring and dissecting. The abdominal cavity was opened through a ventromedian incision beginning roughly at $1 \mathrm{~cm}$ from the external genitalia and extending to the cervical region, followed by two lateral incisions towards the anterior and posterior limbs. The entire gastrointestinal tract was removed, sectioned into its anatomic portions, and washed in biological saline. Samples of the small and large intestines were cut out and fixed in buffered $10 \%$ formalin ( 24 to 48 hours), followed by routine histological technique down to final embedding in paraffin. The material was sectioned into 5 - $\mu \mathrm{m}$ slices in a microtome and stained by the routine haematoxylin and eosin staining technique and by the PAS, Alcian-blue $\mathrm{pH} 2.5$ and Picrosirius red histochemical techniques.

The animals were fixed in $10 \%$ formalin, stored in $70 \%$ alcohol and placed in the scientific collection of the Mastozoology Sector at the National Museum/ UFRJ.

For morphometric analyses the Image Pro Plus software (Media Cybernetics, USA) was used.

\section{RESULTS}

Macroscopic study. The intestine of all species studied showed itself displaced to the right within the abdominal cavity, presenting itself extremely curved (Fig. 1A, B). In D. rotundus this curvature is less noticeable, and the largest part of the intestine is folded back upon itself in a compact series of numerous winding folds (Fig. 1C).

On analyzing the intestine macroscopically we could not distinguish the delimitation between the small and large intestines, in spite of the presence of Peyer's patches. These can be small and difficult to visualize, as in G. soricina. In $S$. lilium and $D$. rotundus we found nodular lymphoid tissue aggregates distributed along the tube. The duodenum can be identified by its diameter, which is bigger than the rest of the gastrointestinal tract.

In $P$. hastatus and $C$. perspicillata we could observe an increase in the diameter of the junction of the small and large intestines, as a result of the presence of Peyer's patches at the end of the distal portion. The large intestines of the analyzed species have neither caeca nor appendices, consisting only of a descending colon. 

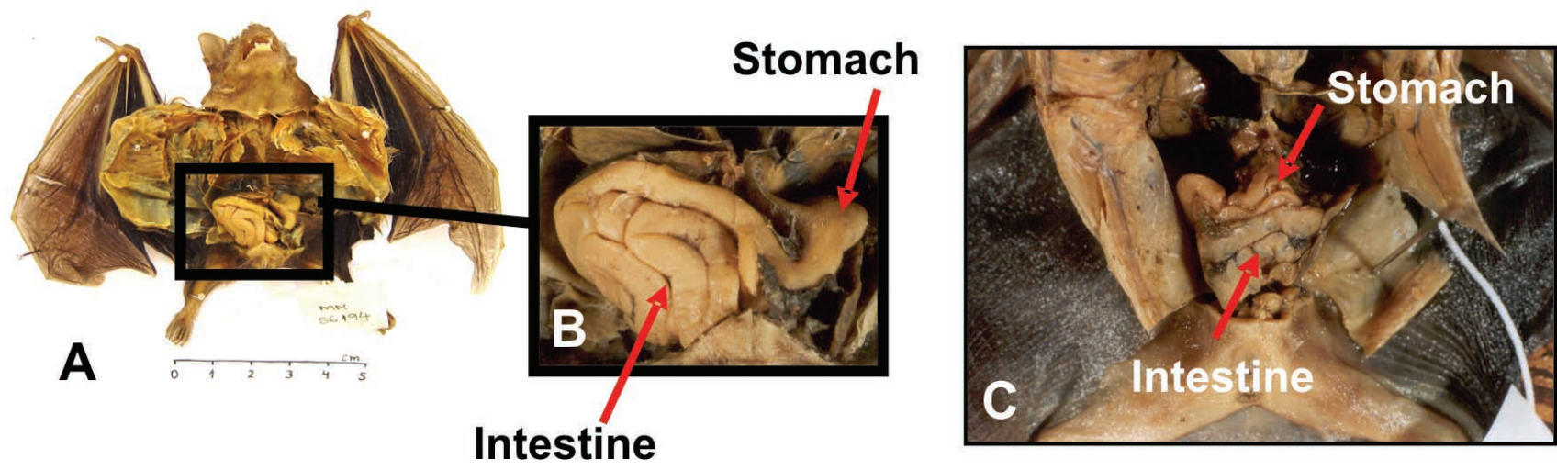

Fig. 1. Photomacrograph of Sturnira lilium showing the (A) anatomic position of the intestine: displaced to the right within the abdominal cavity, extremely curved (B), in detail. Photomacrograph of Desmodus rotundus (C) presenting most of the intestine folded upon itself in a compact series of numerous winding folds.

The intestinal length varies greatly among the species: S. lilium possessing a very long intestine, $P$. hastatus, D. rotundus and $C$. perspicillata having intestines of moderate length, and G. soricina presenting a very short intestine. All measurements were related to body length (Table I).

If the intestine is cut open longitudinally, we observe a series of definite folds in its internal surface. These are Kerckring's folds, which generally run parallel to one another and occupy from half to two-thirds of the tube's perimeter. These folds include the mucosa and part of the submucosa. In the bats studied, these folds are absent in the upper region of the duodenum and in the distal portion as it approaches the colon.

Microscopic study. Histologically, the small intestine wall of the species studied is composed of the typical layers: mucosa, submucosa, muscularis mucosae and serosa.

We observed in all species a mucosa with villi covered by a simple columnar epithelium constituted of absorptive cells, characterized for possessing microvilli (Fig. 2). Scattered among the absorptive cells, the goblet cells can be found. In the middle portion they are less numerous, but distally they increase in number. $D$. rotundus presented fewer numbers of goblet cells throughout the small intestine than the other species.

Shape of villi of the intestinal mucosa presented differences among the species. $C$. perspicillata presented fingerlike villi all over the small intestine, which were longer, arched and arranged in oblique rows in the middle portion, while distally their height decreased (Fig. 3A). In P. hastatus the villi are fingerlike, arched, oblique and long in the middle region (Fig. 3B) whereas, in the distal portion, they were short, more spaced and with not very sharp apices. S. lilium showed villi in two shapes, pyramidal in the middleproximal portion of the duodenum (Fig. 3C), and fingerlike in the other portions (Fig. 3D). The villi are quite long in the middle portion and decrease in the distal portion. G. soricina showed a mucosa with compact, fingerlike villi (Fig. 3E), long in the middle portion and shorter in the distal portion. D. rotundus possesses pyramid-shaped villi (Fig. 3F), longer in the middle portion than in the distal portion.

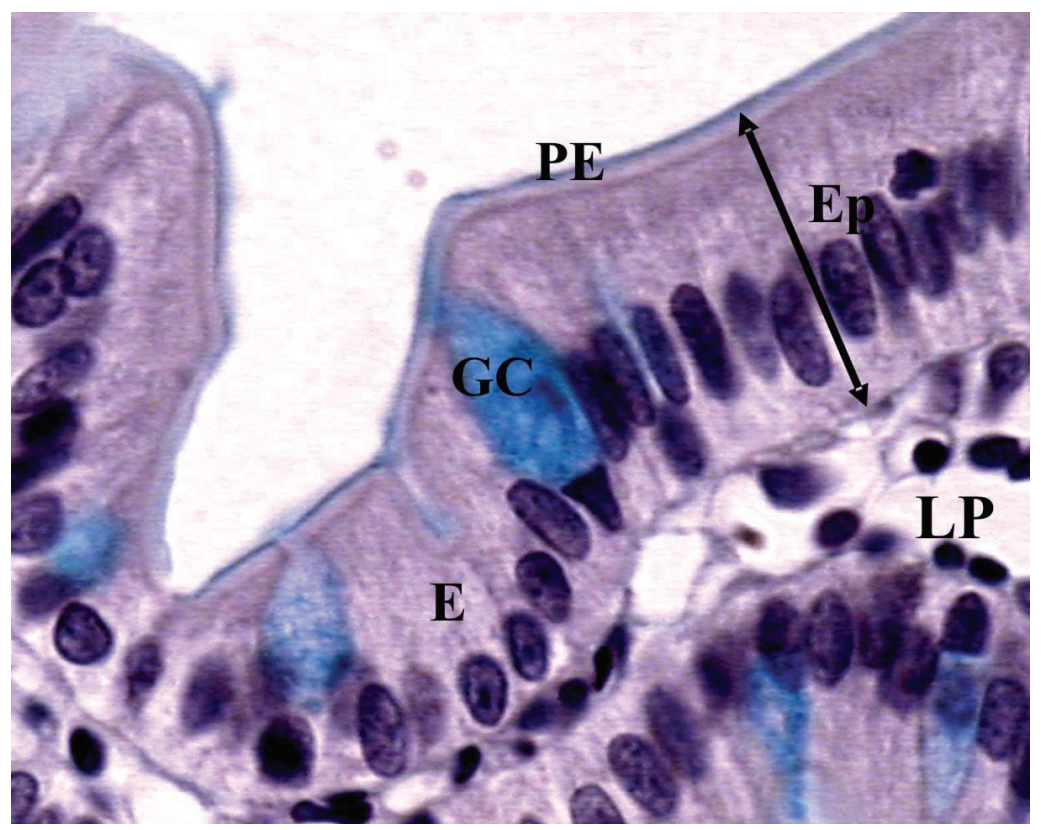

Fig. 2. Photomicrograph of Desmodus rotundus mucosa with villi covered by a simple cylindrical epithelium (Ep) composed of absorptive cells, also known as enterocytes (E), characterized for having striated border (SB). Scattered among the absorptive cells are the goblet cells (GC) $\mathrm{AB}+(\mathrm{AB} 1000 \mathrm{x})$. LP-lamina propria. 
GADELHA-ALVES, R.; ROZENSZTRANCH, A. M. S. \& ROCHA-BARBOSA, O. Comparative intestinal histomorphology of five species of Phyllostomid Bats (Phyllostomidae, Microchiroptera): ecomorphological relations with alimentary habits. Int. J. Morphol., 26(3):591-602, 2008.

Table I. Mean \pm SD intestinal length and body length of the analyzed species.

\begin{tabular}{ccccc}
\hline Species & $\mathrm{n}$ & Intestinal & Body length & Intestinal length/body \\
\hline C.perspici & 5 & $52.4 \pm 12.9$ & $142.6 \pm 3.3$ & 2.7 \\
D. & 5 & $76.9 \pm 13.9$ & $208.5 \pm 4.6$ & 2.7 \\
G. & 5 & $52.6 \pm 6.5$ & $99.8 \pm 1.7$ & 1.9 \\
S. lilium & 5 & $59.7 \pm 24.5$ & $209.6 \pm 1.7$ & 3.5 \\
P. & 5 & $96.7 \pm 9.9$ & $265.6 \pm 4.1$ & 2.7 \\
\hline
\end{tabular}
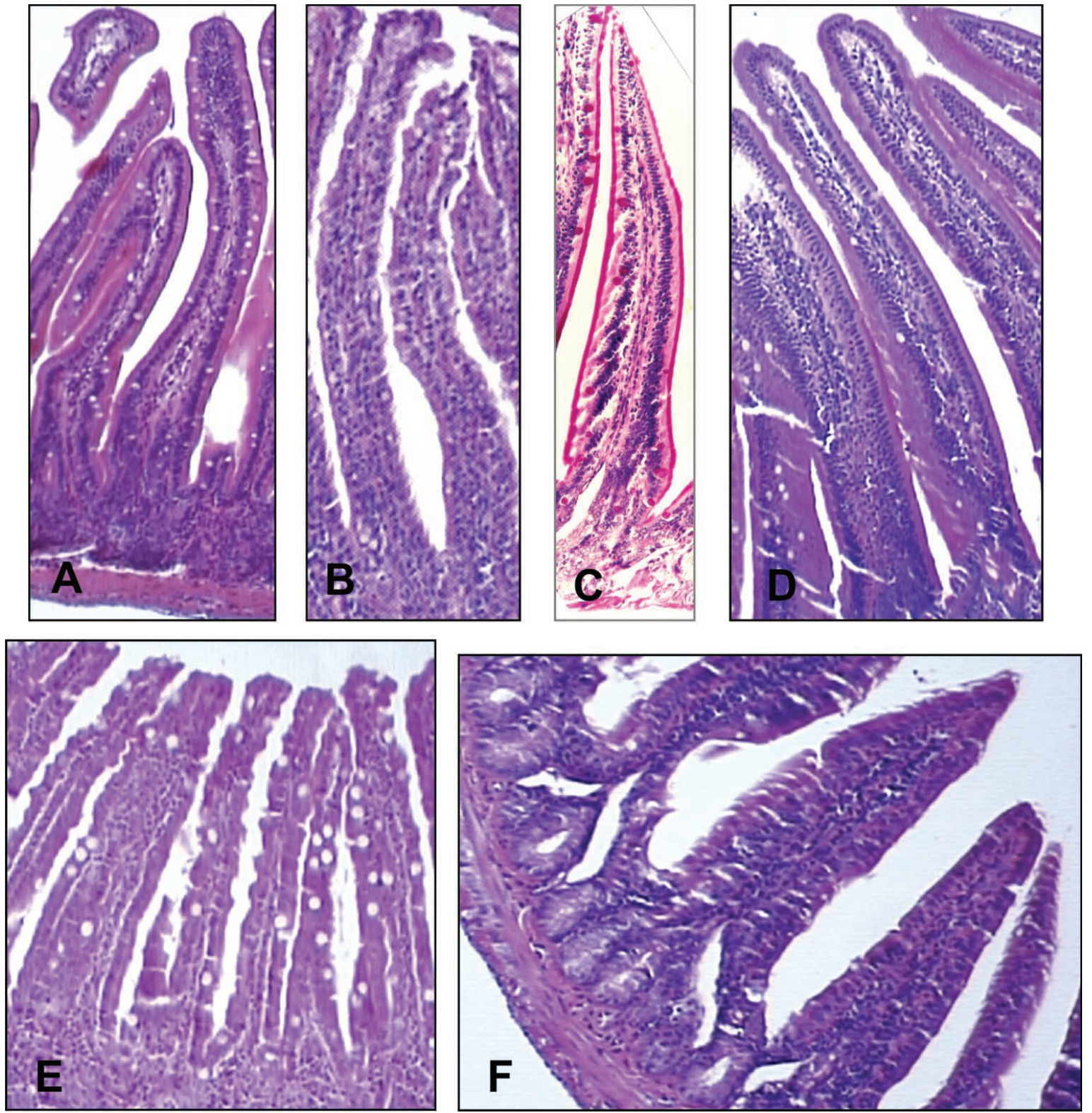

Fig. 3. Villi patterns. (A) Carollia perspicillata, villi fingerlike, long, arched and arranged in oblique rows (H\&E 100x). (B) Phyllostomus hastatus, villi fingerlike, arched, oblique and long in the middle region (H\&E 100x). (C) Sturnira lilium, villi in two shapes, pyramidal in the middle portion close to the duodenum (PAS 100x) and (D) fingerlike in the other portions (H\&E 100x). (E) Glossophaga soricina, mucosa with compact and fingerlike villi (H\&E 100x). (F) Desmodus rotundus, villi with very sharp apices (H\&E 100x). 

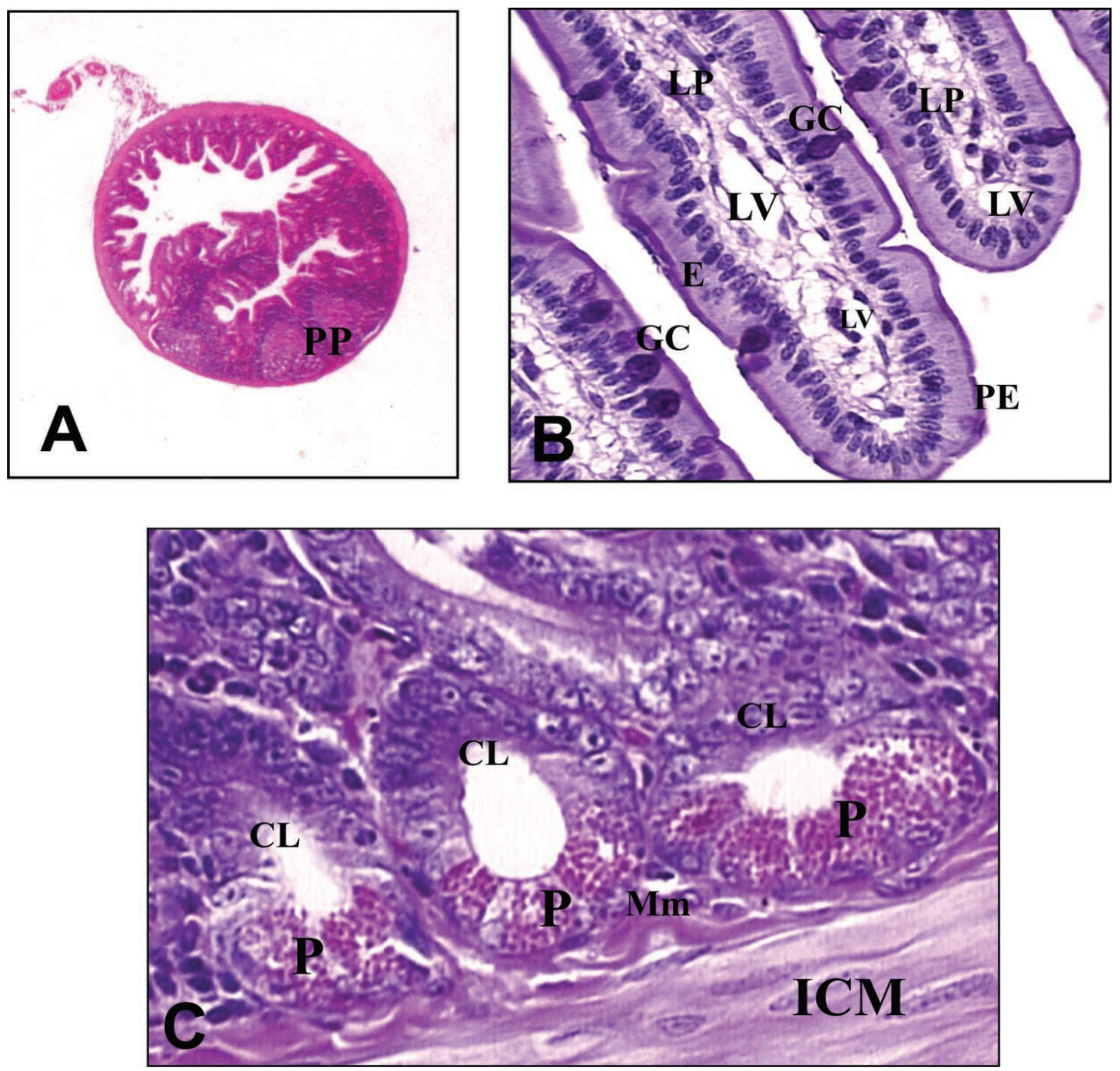

Fig. 4. (A) Panoramic photomicrograph of the small intestine of Desmodus rotundus showing presence of Peyer's patches (PP) (H\&E 10x). (B) Photomicrograph of Carollia perspicillata villi showing the presence of a central lacteal vessel (LV) in the lamina propria (LP) and goblet cells (GC) PAS+ (PAS 400x). (C) Photomicrograph of the crypts of Lieberkühn (CL) of Sturnira lilium with Paneth cells (P) at the base. (H\&E 400x). SB striated border, $\mathrm{Mm}$ - muscularis mucosae, ICM - inner circular muscle layer, E enterocytes, GC - goblet cell.

In the distal portion, next to the junction with the large intestine, we found clustered lymphatic nodules, forming the lumps called Peyer`s patches (Fig. 4A). In the lamina propria of the villi we could see the presence of a discontinuous lacteal vessel, a central lymphatic vessel (Fig. 4B).

Among the villi we found simple tubular glands, the crypts of Lieberkühn (Fig. 4C). These glands are separated by the conjunctive tissue of the lamina propria and their extremities reach the muscularis mucosae. In all the studied species we found, deep in the crypts of Lieberkühn, groups of granular cells known as Paneth cells (Fig. 4C).
Goblet cells were also found in the crypts and, as in the villi, they increase in number in the distal portion. $C$. perspicillata distally presented few goblet cells in its crypts, being more concentrated in the villi (Fig. 4B).

The muscularis mucosae is a very thin tissue layer, and we could not visualize it in the middle portion, but distally it was a little thicker. The submucosa proved to be formed by slack conjunctive tissue possessing blood and lymphatic vessels. In $D$. rotundus the submucosa was denser than in the other species (Fig. 5). 


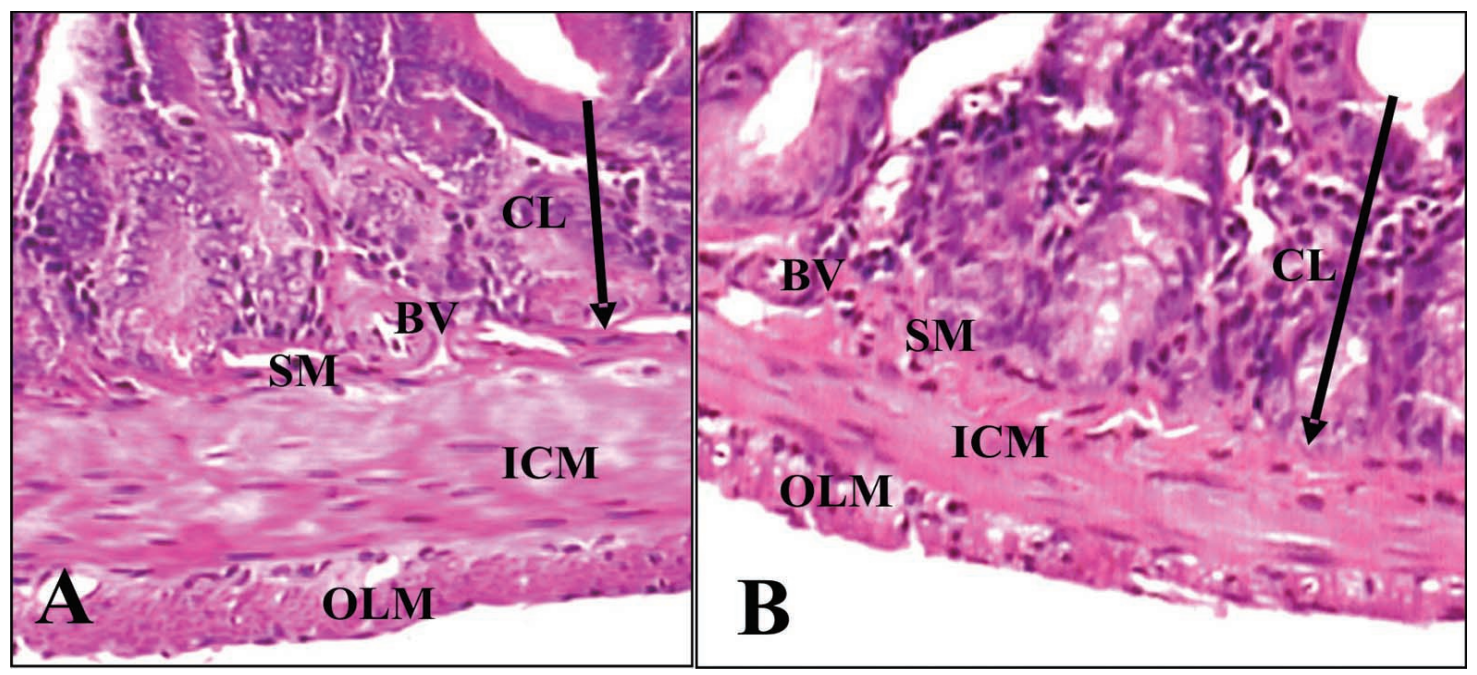

Fig. 5. Photomicrograph of the small intestine showing (A) the very thin submucosa (SM) of Sturnira lilium with blood vessels (BV) (HE 100x) and the (B) thicker submucosa of Desmodus rotundus (H\&E 100x). ICM - inner circular muscle layer, GC - goblet cell, CL - crypts of Lieberkühn, OLM - outer longitudinal muscle layer.

The outer muscular layer is composed of two layers, one circular and another longitudinal. Between them we could visualize the myenteric plexus. In the middle portion the circular and longitudinal layers are very thin, but distally the circular layer becomes much thicker than the longitudinal one (Fig. 6).

Finally, we found the serosa which is the thin, outermost layer, formed by slack conjunctive tissue covered by a mesothelium.

The large intestine of the bats presented uniform characteristics, being formed by only a descending colon and the rectum. All four layers were present: mucosa, submucosa, muscular and serosa.

The mucosa is smooth, without the presence of villi or folds as in the small intestine. The whole thickness of the mucosa is filled with intestinal glands (crypts of Lieberkühn) which are long, straight and tubular.

The superficial epithelium as well as the glands epithelium is of the simple columnar type and contains absorptive cells and innumerous goblet cells. The submucosa is formed by a slack conjunctive tissue containing blood vessels. The muscularis layer is divided in two, one very thick
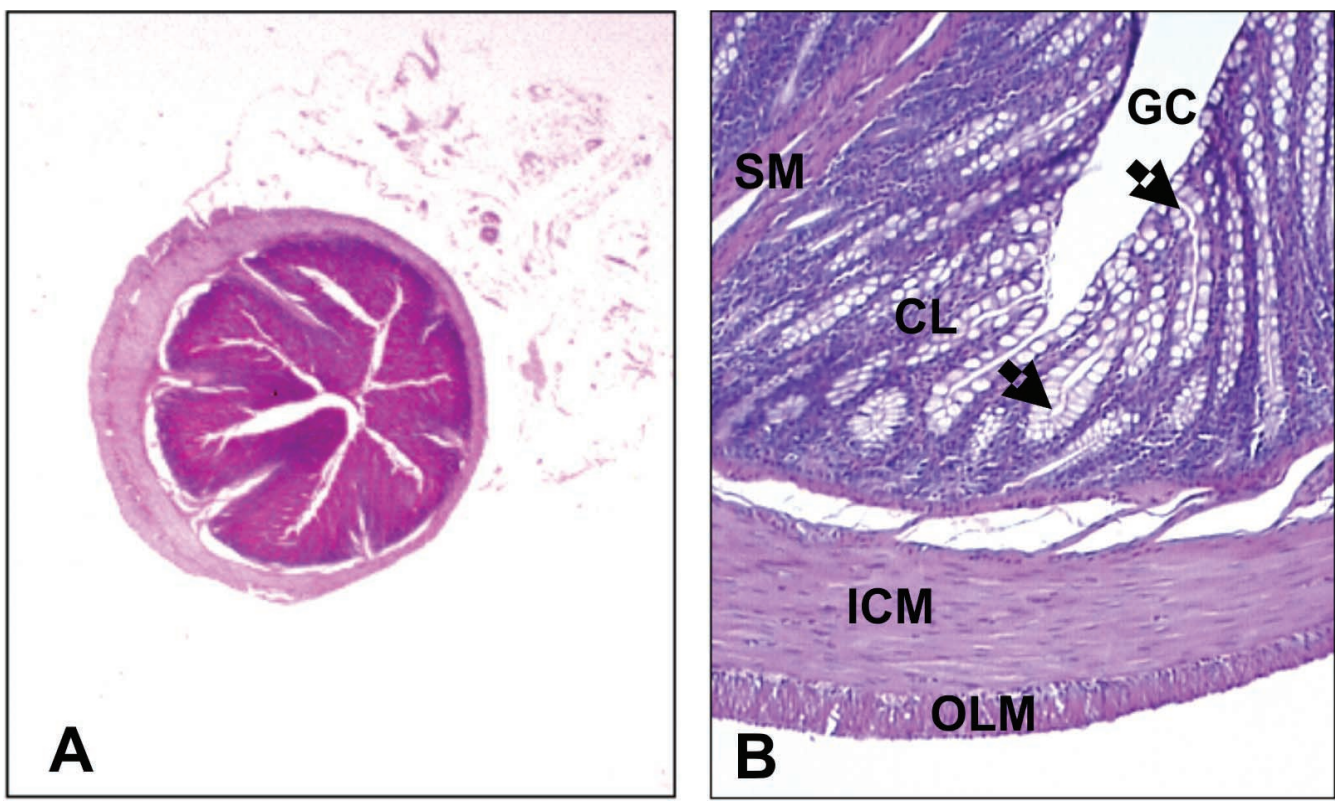

Fig. 6. Large intestine of Phyllostomus hastatus in (A) a panoramic photomicrograph (PAS 10x) and (B) a photomicrograph. Note the absence of villi in the mucosa. The crypts of Lieberkühn (CL) occupy the entire mucosa. Numerous goblet cells (GC) are found and the inner circular muscular layer (ICM) is thicker than the outer longitudinal one (OLM) (H\&E 100x). SM submucosa. 

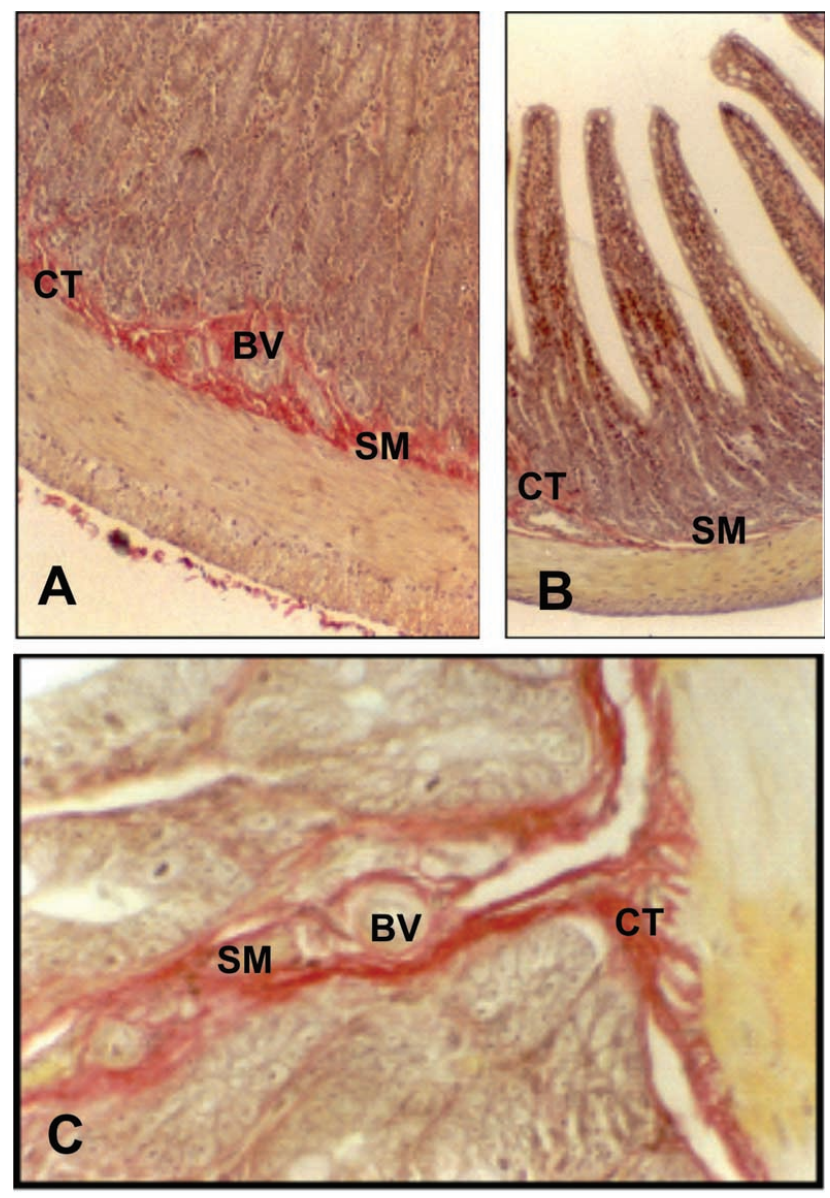

Fig. 7. Photomicrographs of the small intestine of (A) Phyllostomus hastatus, showing abundant conjunctive tissue (CT) in the submucosa (SM) and of (B) Carollia perspicillata, showing scarce conjunctive tissue (CT) in the submucosa (SM) (Picro-sirius 100x). BV - blood vessels. (C) Photomicrographs of the large intestine of Glossophaga soricina showing abundant conjunctive tissue (CT) in the submucosa (SM) and around the blood vessels (BV). (Picro-sirius 400x).

and circular, and the other thin and longitudinal. The serosa is very thin, with abundant conjunctive tissue around the vessels.

Structures that are characteristic of the large intestines of mammals, like taeniae coli and appendices epiploicae, were not found in the species studied.

In the present work we used methods of routine staining as well as some special dyes (histochemistry). We used the Periodic Schiff Acid (PAS) to detect the presence of glycoproteins in the goblet cells of the small and large intestines. These cells tested positive for all regions of the small and large intestines of all studied species.

In all species the alcian blue $\mathrm{pH} 2.5$ method tested positive for the carboxylated proteoglycans of the goblet cells all over the intestine (small and large).
The collagen distribution in the small intestine presented differences among species, being abundant in the submucosa and around the serosa vessels in P. hastatus, $G$. soricina and $D$. rotundus, but scarce in the submucosa of $C$. perspicillata and $S$. lilium. In the large intestine collagen was abundant in all species. This analysis was done using the picro-sirius method without polarization (Fig. 7A, B and C).

Under a polarized light we could notice the organization of the collagen network, which appeared to be type-I for being birefringent and displaying red-orange shades in the small and large intestine of all species studied.

The length of the crypts of Lieberkühn and of the villi both in the middle portion of the small intestine were morphometrically analyzed (Table II and III; Fig. 8). In P. hastatus the crypts were longer than in the other species, and in D. rotundus they were shortest (Table II and Fig. 8A). The villi presented differences in length. S. lilium and $C$. perspicillata presented longer villi than $P$. hastatus, $D$. rotundus and G. soricina (Table III and Fig. 8B).
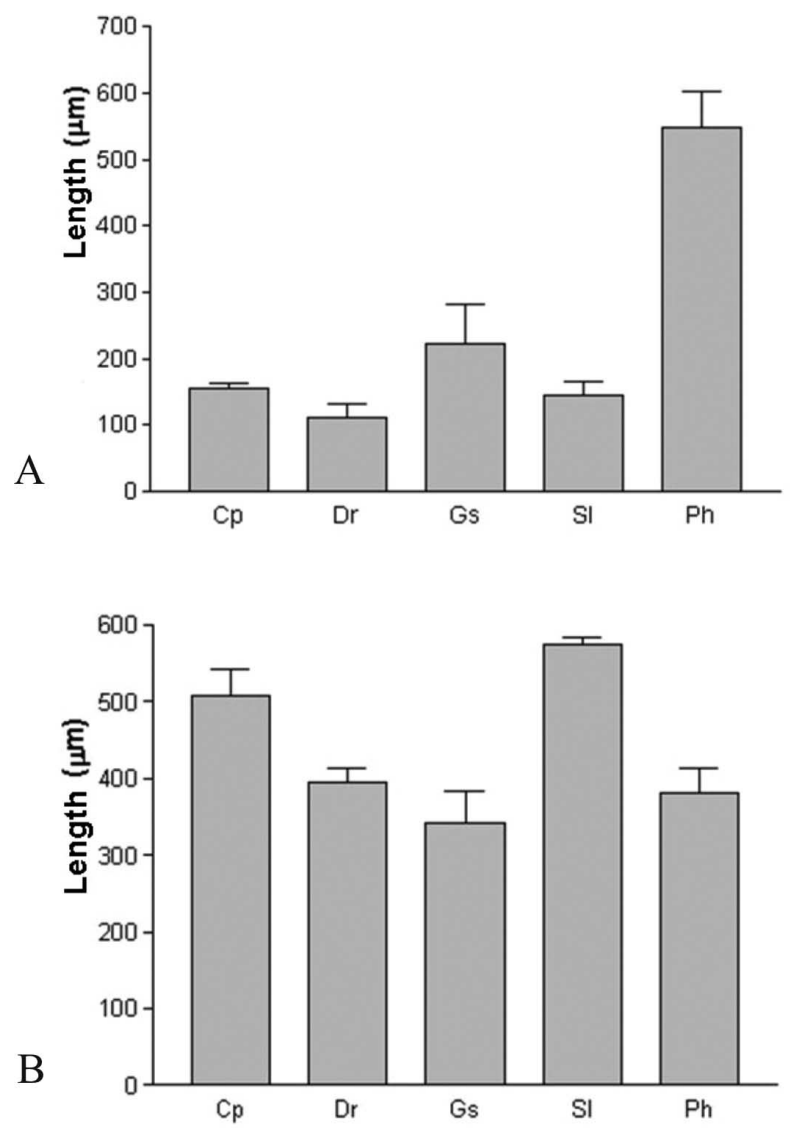

Fig. 8. Morphometric values for each of the specimens studied, regarding (A) the crypts of Lieberkühn lengths $(\mu \mathrm{m})$ and (B) villi length $(\mu \mathrm{m})$. Cp (Carollia perspicillata), Dr (Desmodus rotundus), Gs (Glossophaga soricina), Sl (Sturnira lilium), Ph (Phyllostomus hastatus). 
GADELHA-ALVES, R.; ROZENSZTRANCH, A. M. S. \& ROCHA-BARBOSA, O. Comparative intestinal histomorphology of five species of Phyllostomid Bats (Phyllostomidae, Microchiroptera): ecomorphological relations with alimentary habits. Int. J. Morphol., 26(3):591-602, 2008.

Table II. Morphometric measurements of the Lieberkühn crypts lengths $(\mu \mathrm{m})$.

\begin{tabular}{cccccc}
\hline Specimen & Carollia & Desmodus rotundus & Glossophaga & Sturnira lilium & Phyllostomus \\
& perspicillata & & soricina & hastatus \\
\hline 1 & 172.792 & 79.499 & 155.580 & 119.477 & 424.286 \\
2 & 147.999 & 146.956 & 168.801 & 124.504 & 536.448 \\
3 & 144.177 & 108.335 & 342.970 & 188.853 & 688.676 \\
4 & - & - & - & - & 548.211 \\
Mean & 154.989 & 111.597 & 222.450 & 144.278 & 549.405 \\
SD & 15.535 & 33.846 & & 38.685 & 108.350 \\
\hline
\end{tabular}

Table III. Morphometric measurements of villi length $(\mu \mathrm{m})$.

\begin{tabular}{cccccc}
\hline Specimen & Carollia & Desmodus rotundus & Glossophaga & Sturnira lilium & Phyllostomus \\
& perspicillata & & soricina & hastatus \\
& & & & & 464.860 \\
2 & 568.800 & 368.520 & 338.230 & 594.030 & 334.020 \\
3 & 509.050 & 424.070 & 273.080 & 564.000 & 445.340 \\
4 & 444.620 & 396.290 & 415.080 & - & 326.430 \\
\hline Mean & - & - & - & 574.296 & 382.287 \\
\hline SD & 507.490 & 396.293 & 342.130 & 17.095 & 60.862 \\
\hline
\end{tabular}

\section{DISCUSSION}

Intestines in the analized species are located in the same position as in the different species of Chiroptera studied by Park \& Hall, (1951); Forman et al.; Tedman \& Hall, (1985).

The intestine of $D$. rotundus is similar to that described by Forman et al., displaying very little noticeable curving, while in the other species the shape was arched, as reported by Schultz, (1965).

Special techniques like light and scanning electron microscopy have been used to distinguish the different portions of bat intestines, e.g. by Okon (1977); Ishikawa et al. (1985); Tedman \& Hall (1985); Makanya \& Maina (1994); Makanya (1997), Makanya et al. (2001).

External morphology does not allow a clear distinction between the small and large intestines in all bat species. Tedman \& Hall (1985) stated that the intestine of Pteropus alecto and $P$. poliocephalus is a continuous tube without separation between the small and large intestines. Forman, (1974a, b) states that the junction of the small and large intestine is formed by a small ampulla, resulting from abundant lymphoid tissue (Peyer's patches). He revealed differences in the abundance, distribution and morphology of these tissues in phyllostomids which are possibly diet related. He also noted that frugivorous bats have more Peyer's patches than nectarivorous, carnivorous or insectivorous ones, and that they can occur anywhere along the tract. In insectivorous and carnivorous species, the patches are small, showing a low state of activity, and usually restricted to the ileum submucosa. In S. lilium and D. rotundus we noticed a greater number of aggregates of lymphoid nodular tissue, which are well distributed along the tract. In P. hastatus and $C$. perspicillata Peyer`s patches were observed in the distal portion next to the large intestine, and the two portions of the intestine (small and large) could be distinguished. In G. soricina we could not visualize Peyer's patches externally, and so it was not possible to delimit the small/large intestine junction, as also observed by Ishikawa et al., in the insectivorous bat Myotis frater.

The absence of the caecum and of the appendix is considered characteristic of the gastrointestinal tract of chiropterans (Tedman \& Hall), another feature being the absence of the ascending and transverse colons, the large 
intestine as a result being restricted to a descending short colon (Forman et al.). This absence is well described in the literature for several species of bats (e.g. Park \& Hall, Ishikawa et al.; Tedman \& Hall; Makanya \& Maina; Makanya; Makanya et al., 2001), and this also applies to all species studied in the present work.

Most bats have a smaller intestine than do terrestrial mammals of comparable size (Klite, 1965). Several comparisons of bat intestinal length measurements (Robin 1881; Eisentraut 1950, Park \& Hall; Forman et al.; Tedman \& Hall; Makanya) reveal that frugivorous species have a longer intestine, relative to body length, than species with other feeding habits.

Eisentraut, observed a great number of bat species with a variety of feeding habits and noted that those with intestines four times longer than the body were always frugivorous species. Among the species with a longer intestine were Chiroderma villosum, Vampyrops vittatus and several species of Artibeus. Vampire bats presented intestines of moderate length and insectivorous ones a short gastrointestinal tract. Comparable measurements were taken in this work and we noted that $S$. lilium, frugivorous, has a long intestine relative to body length. In D. rotundus, $P$. hastatus and $C$. perspicillata intestine length is moderate, and in G. soricina it is short. The latter is similar to the insectivorous species in that it supplements its diet with insects. The short intestine observed in this species is probably an adaptation to reduce weight for improving flight. Physiological studies made by Keegan (1975, 1977) indicated that long intestines would not hamper the flight of frugivorous bats, since food transit and absorption time is quite rapid.

The disposition of Kerckring's folds, absent in the upper region of the duodenum and in the distal portion as it approaches the colon, are similar to that generally found in mammals.

The gland of Brunner is easily found in the duodenum of bats, but the taenia coli and the appendices epiploicae are absent in the large intestines of the species analized in this work, as well as in the ones studied by Tedman \& Hall; Makanya \& Maina; Makanya; Makanya et al. (2001).

We can distinguish the intestine segments by the increase of the goblet cells and the absence of villi, which are typical of the chiropteran large intestine. The middle and distal portions can be distinguished by decrease of the villi and increase of the goblet cells in the distal portion, also observed by Ishikawa et al.; Tedman \& Hall; Makanya \& Maina in other species.
The villi of the small intestine mucosa presented differences, similar to the ones described by Mathis (1928); Schultz; Forman et al. The mucosa epithelium, similar to that found in other mammals, is of the simple columnar type, which was also observed in Myotis frater by Ishikawa et al., in Pteropus alecto and P. poliocephalus by Tedman \& Hall and in Epomophorus wahlbergi by Makanya et al. (2001).

The cell types found in the small intestine of the bats studied are basically the same found in mammals in general, i.e. absorptive cells which microvilli and goblet cells which become more numerous along the tube. This was observed in other species of bats by Ishikawa et al.; Tedman \& Hall; Makanya \& Maina; Makanya; Makanya et al. (1995, 2001). D. rotundus presented less goblet cells than the other species, a fact also observed in Pteropus alecto by Tedman \& Hall. This can be associated to the type of food consumed, which is liquid and easily absorbed. D. rotundus is sanguivorous.

Paneth cells were observed by Schaaf (1970) in the insectivorous species group: Artibeus jamaicensis, Bachyphylla nana, Phyllonycteris polyi and Monophyllus redmani. These cells were also observed in all the analyzed species.

The presence of glycoproteins and carboxylated proteoglycans in goblet cells is a common characteristic in mammals, including man.

The muscularis mucosae and submucosa are not highly developed in the species here described, a fact also observed in Myotis frater by Ishikawa et al., but blood and lymphatic vessels were well observed in the submucosa. In D. rotundus this layer was thicker than the others, a characteristic previously observed by Forman et al., in vampire bats.

Many characteristics generally found in mammals were also seen in bats, such as the presence of central lacteals in the lamina propria of the villi, and an outer muscular layer composed of a circular and a longitudinal layer, the former increasing in thickness as it approaches the large intestine. A myoentheric plexus was observed between them and the outermost layer, the serosa, was formed by slack conjunctive tissue covered by a mesothelium.

The presence of colagen fibers in the intestine of mammals is common. It is believed that in the large intestine this colagen layer regulates the transport of substances which are absorbed. In the small and large intestines of all studied species a dense colagen network was found, seemingly of type I. The characteristics of the large intestine are uniform in the studied species, as well as in the ones already described in the literature. 
Morphometric studies of the bat gastrointestinal tract are scarce in the literature. These studies are essential to determine important functional parameters, such as the absorption surface area available in different kinds of bats.

We may conclude that the patterns of morphological variation observed in the small intestine suggest adaptations to the different feeding habits of the bat species here studied. These results can be used as a new and promising systematic approach for formulating rules of variation concerning the histological patterns observed, to corroborate existing hypotheses or to create grounds for new studies.

\section{List of specimens used.}

- Phyllostomus hastatus (Subfamily Phyllostominae): MN 56210, MN 56233, MN 56234, MN 56235, MN 56236, MN 56238, MN 59715, MN 59835.

- Carollia perspicillata (Subfamily Carolliinae): MN 56262, MN 56289, MN 56292, MN 56293, MN 56324, MN 56352, MN 59694, MN 59696, MN 59721, MN 59732, MN 59739, MN 59803, MN 59810.

Desmodus rotundus (Subfamily Desmodontinae): MN 56164, MN 56190, MN 59710, MN 59711; MN 59724 , MN59743, MN 59766, MN 59778; MN 59823; MN 59830.

- Sturnira lilium (Subfamily Stenoderminae): MN 56186, MN 56194, MN 56342, MN 56344, MN 56345, MN 59697, MN 59716, MN 59749, MN 59750, MN 59755, MN 59761, MN 59817.

- Glossophaga soricina (Subfamily Glossophaginae):
MN 56156, MN 56157, MN 56278, MN 56278, MN 56302, MN 56308, MN 56309, MN 56310, MN 56333, MN 56335, MN 59758.

\section{ACKNOWLEDGEMENTS}

We thank Dr. Leandro de Oliveira Salles from the Mastozoology Sector of the National Museum of Rio de Janeiro /UFRJ for the use of his laboratory and permission to take part in the collections performed in Serra da Bodoquena, Mato Grosso do Sul State; Dr Patrícia Gonçalves Guedes and Carlos Augusto Caetano for their help in some collecting trips; Prof. Hamilton G. dos Santos for his help in the field trips and in species identification; Dr. Leonardo dos Santos Ávilla for the collections in Carmo - RJ State and for his help with species identification; Dr. Carlos Alberto Mandarim-de-Lacerda from the UERJ Anatomy Department for ample use of his laboratory; Dr Mara Íbis Rodrigues Apfel and Dr Jorge José de Carvalho from the UERJ Histology and Embriology Department for hints on histological and histochemical staining methods and the use of the laboratory; João Roberto de Campos Perez and Francisco Fábio da Silva Barbosa from the UERJ Histology and Embriology Department for help in preparing histological slides; Mário Pereira from the UERJ Physiology Department for his help with the morphometric analyses; Mariana Fiuza de Castro Loguercio for helping in the text revision and Humberto Moura-Neto for his help in revising the English translation.

GADELHA-ALVES, R.; ROZENSZTRANCH, A. M. S. \& ROCHA-BARBOSA, O. Histomorfometría comparativa de intestino de cinco especies de murciélagos phyllostomideos (phyllostomidae, microchiroptera): relaciones ecomorfológicas con habitos alimentarios. Int. J. Morphol.,26(3):591-602, 2008

RESUMEN: Los intestinos de Sturnira azucenas, Phyllostomus hastatus, Carollia perspicillata, Glossophaga soricina y Desmodus rotundus se analizaron a través de estudios macroscópicos, morfométricos y de microscopía de luz. Las especies estudiadas presentan algunas características comunes en general encontradas en murciélagos, tales como la ausencia de un ciego y un apéndice. Murciélagos frugívoros S. azucenas tienen un intestino más largo que el de otras especies. El epitelio intestinal es de tipo columnar simple, constituido por células de absorción que se caracterizan por microvellosidades y células caliciformes, que en todas las especies resultó ser PAS + y $\mathrm{AB}+$. Estas células presentan algunas diferencias en cantidad y en la distribución entre las especies. La mucosa intestinal presenta diferencias morfológicas y morfométricas, como la forma y el tamaño de las vellosidades, así como la longitud de las criptas de Lieberkühn. Histológicamente las diferentes partes intestinales pueden ser distinguidas: en la parte media encontramos pocas células caliciformes y largas vellosidades, en la porción distal encontramos un aumento de células caliciformes y una disminución en la altura de vellosidades, y en el intestino grueso no se encontraron vellosidades, sino más bien abundantes glándulas intestinales con numerosas células caliciformes. En C. perspicillata, P. hastatus y G. soricina podemos observar placas de Peyer en la porción distal, cerca del intestino grueso, mientras que en $D$. rotundus y $S$. azucenas se encontraron agrupaciones de tejido linfoide nodular distribuido a lo largo del tubo. En todas las especies se observó la presencia de células Paneth en la base de las criptas de Lieberkühn. Hemos podido observar diferencias entre las especies en la distribución de colágeno en el intestino delgado y submucosa serosa. La capa muscular exterior tiene una capa circular y una capa longitudinal, la capa circular en el aumento de espesor a lo largo del tubo. Las características del intestino grueso son uniformes entre las especies. Estructuras como la taenia coli y los apéndices epiploicos estuvieron ausentes. Estos resultados deben contribuir no sólo a mejorar la comprensión de la morfología del murciélago, sino también para sentar las bases para la evaluación de los modelos evolutivos adaptativa de la radiación en los hábitos alimenticios de filostómidos.

PALABRAS CLAVE: Intestinos; Murciélagos; Phyllostomidae; Histología; Histoquímica; Micrometría; Ecomorfología. 
GADELHA-ALVES, R.; ROZENSZTRANCH, A. M. S. \& ROCHA-BARBOSA, O. Comparative intestinal histomorphology of five species of Phyllostomid Bats (Phyllostomidae, Microchiroptera): ecomorphological relations with alimentary habits. Int. J. Morphol., 26(3):591-602, 2008.

\section{REFERENCES}

Bhide, S. A. Observations on the anatomy, histology and histochemistry of the stomach of the vespertilionid bat Miniopterus schreibersii (Kuhl). Proc. Indian Acad. Sci., 88b:1-12, 1979.

Eisentraut, M. Die Ernährung der Fledermäuse (Microchiroptera). Zool. Jahrb., 79:114-7, 1950.

Forman, G. L. Gastric morphology in selected mormopid and glossophagine bats as related to systematic problems. Trans. Illinois Acad. Sci., 64:273-82, 1971.

Forman, G. L. Comparative morphological and histochemical studies of the stomachs of selected American bats. Univ. Kansas Sci. Bull., 59:591-729, 1972.

Forman, G. L. Studies of gastric morphology in North Americam Chiroptera (Emballonuridae, Noctilionidae, and Phyllostomatidae). J. Mammal., 54:909-23, 1973.

Forman, G. L Comparative studies of organized gutassociated lymphoid tissue in mammals with diverse food habits. Distribuition, size, and organization of Payer's patches in New World bats. Trans. Illinois. Acad. Sci., 67:152-6, 1974a.

Forman, G. L. The structure of Peyer's patches and their associated nodules in New World bats in relation to food habits. J. Mammal., 55:738-46, 1974b.

Forman, G. L.; Phillips, A. J. \& Rouk, C. S. Alimentary tract. p. 205-227. In: Baker, R.J., Jones Jr., J.K., Carter, D.C., eds. Biology of bats of the New World Family Phyllostomatidae. Part III. Spec. Publ. Mus. Texas Tech. Univ., 16:1-441, 1979.

Gardner, A. L. Feeding habits. pp.293-350. In: Baker, R.J., Jones Jr., J. K., Carter, D.C., eds. Biology of bats of the New World Family Phyllostomatidae. Part II. Spec. Publ. Mus. Texas Tech. Univ., 13:1-364, 1977.

Gimenez, E. A. Análise cladística e sistemática da família Phyllostomidae e outros Noctionoidea (Mammalia: CHIROPTERA). PhD thesis. Botucatu, SP: Universidade Estadual Paulista, 1998. p168.

Ishikawa, O. K.; Matoba, M.; Tanaka, H. \& Ono, K. Anatomical study of the intestine of the insect feeder bat, Myotis frater kaguae. J. Anat., 142:141-50, 1985.
Kamiya, T. \& Pirlot, P. Comparative gastric morphology of Old World bats. Part 1. In light microscopy. J. Mammal. Soc. Jap., 6:145-54, 1975.

Keegan, D. J. Aspects of absorption of fructose in Rousettus aegypticus. S. Afri. J. Med. Sci., 40: 49-55, 1975.

Keegan, D. J. Aspects of the assimilation of sugars by Rousettus aegypticus. Comp. Biochem. Physiol. Part A Comp. Physiol., 58:349-52, 1977.

Klite, P. D. Intestinal bacterial flora and transit time in three neotropical bat species. J. Bacteriol., 90:375-9, 1965.

Koopman K. F. Order Chiroptera In: Wilson D. E. \& Reeder, D. M., eds. Mammal species of the world: a taxonomic and geografic reference. $2^{\text {nd }} e d$. Washington \& London, Smithsonian Institution Press, 1993, pp.137-241.

Madkour, G. A. A comparative study of certain features of the alimentary canal and disposition of the viscera in Egyptian bats. Ann. Zool. (Agra), 13:63-81, 1977.

Makanya, A. N. The morphology of the intestine of the entomophagous longfingered bat, Miniopterus inflatus: mucosal topography and possible landmarks. Acta Biol. Hung., 48:15-27, 1997.

Makanya, N. A. \& Maina, J. N. The morphology of the intestine of the insectivorous horseshoe bat (Rhinolophus hildebrandti, Peters): a scanning electron and light microscopic study. African J. Ecology, 32(2):158-68, 1994.

Makanya, A. N.; Mayhew, T. M. \& Maina, J. N. Stereological methods for estimating the functional surfaces in the chiropteran small intestine. J. Anat., 187:361-8, 1995

Makanya, A. N.; Self, T. J.; Warui, C. N. \& Mwangi, D. K. Gut morphology and Morphometry in the epauletted Wahlberg's fruit bat (Epomophorus Wahlbergi, Sundervall, 1846). Acta Biol. Hung., 52(1):75-89, 2001.

Mathis, J. Beitrag Zur Kenntnis des Fledermausdarmes. Z. Mkrosk. Anat. Forsch., 192(8):595-647, 1928.

Okon, E. E. Functional anatomy of the alimentary canal in the fruit bat, Eidolon helvum and the insect bat, Tadarida nigeriae. Acta Zool. (Stockh.), 58:83-93, 1977. 
GADELHA-ALVES, R.; ROZENSZTRANCH, A. M. S. \& ROCHA-BARBOSA, O. Comparative intestinal histomorphology of five species of Phyllostomid Bats (Phyllostomidae, Microchiroptera): ecomorphological relations with alimentary habits. Int. J. Morphol., 26(3):591-602, 2008.

Park, H. \& Hall, E. R. The gross anatomy of the tongues and stomachs of eight New World bats. Trans. Kansas Acad. Sci., 54:64-72, 1951.

Robin, H. A. Recherches anatomiques sur les Mammifères de l'ordre des Chiropteres. Ann. Sci. Nat. Zool., 12:1$180,1881$.

Rouk, C. S. \& Glass, B. P. Comparative gastric histology of five North and Central American bats. J. Mammal., 51:455-76, 1970.

Schaaf, V. P. Untersuchungen über das histochemische Verhalten der Panethschen Kornerzellen bei mittelamerikanischen Fledermausarten mit unterschiedlichen Ernährungsweisen. Anat. Anz. Bd., 126:275-7, 1970.

Schultz, W. Studien über den Magen-Darm-Kanal der Chiropteren. Z. Wiss. Zool., 171:240-391, 1965.

Tedman, R. A. \& Hall, L. S. The morphology of the gastrointestinal tract and food transit time in the fruit bats Pteropus alecto and $P$. poliocephalus (Megachiroptera). Aust. J. Zool., 33:625-40, 1985.
Correspondence to: Oscar Rocha-Barbosa Universidade do Estado do Rio de Janeiro

Pav. Haroldo Lisboa da Cunha - sl. 522a, 5o Andar Departamento de Zoologia LAZOVERTE - Laboratório de Zoologia de Vertebrados (Tetrapoda)

Rua São Francisco Xavier, 524 - Maracanã 20550-013

Rio de Janeiro, RJ,

BRASIL

\section{E-mail: obarbosa@uerj.br}

Received:28-03-2008

Accepted:04-08-2008 